CHARLES W. CALOMIRIS

Northwestern University

R. GLENN HUBBARD

Northwestern University

JAMES H. STOCK

Harvard University

\title{
The Farm Debt Crisis and Public Policy
}

U.S. FARMS, and with them agriculturallending institutions, are currently experiencing their most severe stress since the 1930s. From 1980 to 1984, the average real value of U.S. farmland dropped by 29 percent. The decline has been most pronounced in the Corn Belt and Northern Plains states that produce cash grains, general livestock, and dairy products; in Nebraska, for example, the real value of farmland is half what it was in 1980. The erosion in the value of equity has had the effect of increasing the leverage of many farm borrowers. Delinquent loans have increased substantially, hitting 7.5 percent of total loans at small agricultural banks by mid-1985.

Agricultural bank earnings are down and bank failures are up. In 1983, seven insured commercial agricultural banks failed; in 1984 and 1985, the figure rose to thirty-two and sixty-eight, respectively. Agricultural banks accounted for 41 percent of the insured commercial banks that

We are grateful to participants in the 1986 National Bureau of Economic Research Summer Institute Workshop on Contracting in Financial Markets and the Faculty Research Seminar at the John F. Kennedy School of Government, and to Francis Bator, Ben Bernanke, Steve Fazzari, Lewis Kochin, Bruce Petersen, James Poterba, Robert Weiner, Richard Zeckhauser, and members of the Brookings Panel for helpful comments and suggestions; and to Julie Lopez, John Shea, John Simpson, and Raidza Torres for excellent research assistance. We have benefited extensively from advice and information from Gary Benjamin at the Federal Reserve Bank of Chicago; Cala Fsasz at the Farmers Home Administration; Jerry Hansen at the Center for Rural Affairs; Robert Jensen, James Schurr, and their colleagues at the Farm Credit Corporation of America; Emanuel Melichar at the Federal Reserve Board; James Roll at the Federal Farm Credit Banks Funding Corporation; and Peter Timmer at the Harvard Business School. 
failed in 1984; in every quarter since, they have accounted for more than half of total bank failures. Agricultural banking in general has become substantially more fragile. In 1984, more than 20 percent of total agricultural loans outstanding at banks were to borrowers with a debtequity ratio in excess of 70 percent and a negative cash flow. The government-sponsored Cooperative Farm Credit System (FCS) has suffered similar portfolio deterioration and now faces an imminent threat of insolvency, though legislation passed by Congress in 1985 provides for stopgap assistance from the federal government. Total outstanding farm loans likely to default have been estimated at between $\$ 80$ billion and $\$ 100$ billion. ${ }^{1}$

Until recently, the major source of the U.S. farmers' trouble during the 1980s has been severe national and international economic shocks: increased foreign farm output, an overvalued dollar, and high U.S. interest rates. But U.S. farm credit markets have now become yet another source of trouble as they propagate the shocks in the farm sector. $^{2}$

1. These summary statistics are drawn from Emanuel Melichar and George D. Irwin, "Condition of Rural Financial Intermediaries," American Journal of Agricultural Economics, vol. 67 (December 1985, Proceedings Issue), pp. 1178-83; Dallas S. Batten and Michael T. Belongia, "Monetary Policy, Real Exchange Rates, and U.S. Agricultural Exports," American Journal of Agricultural Economics, vol. 68 (May 1986), pp. 422-27; Emanuel Melichar, “Agricultural Banks under Stress," Federal Reserve Bulletin, vol. 72 (July 1986), pp. 437-48.

2. This view of supply-side failures in credit markets as being an important determinant of economic activity has received increasing attention (see for example Ben Bernanke, Alan Blinder, and Benjamin Friedman). However, empirical attempts to ascertain the role of credit constraints in determining economic activity have been confined to historical data pertaining to the National Banking Era (in Charles Calomiris and Glenn Hubbard) or to the Great Depression (in Ben Bernanke). While these historical analyses are suggestive, more relevant to the issues raised in current deregulatory and farm policy debates would be an investigation of the quantitative importance of credit supply effects on output that might have arisen over the past several years in the farm sector. Ben S. Bernanke, "Nonmonetary Effects of the Financial Crisis in the Propagation of the Great Depression," American Economic Review, vol. 73 (June 1983), pp. 259-76; Alan S. Blinder, "Credit Rationing and Effective Supply Failures," Working Paper 1619 (National Bureau of Economic Research, May 1985); Benjamin M. Friedman, "The Relative Stability of Money and Credit 'Velocities' in the United States: Evidence and Some Speculations," Working Paper 645 (National Bureau of Economic Research, March 1981); Charles W. Calomiris and R. Glenn Hubbard, "Price Flexibility, Credit Rationing, and Economic Fluctuations: Evidence from the U.S., 1879-1914," Working Paper 1767 (National Bureau of Economic Research, October 1985). 
This paper examines potential imperfections in agricultural credit markets based on "agency" and "information" considerations. Information-intensive localized customer borrowing relationships, rather than impersonal debt and equity markets, are important in agricultural finance. Reliance on local relationships, however, is complicated by regulatory restrictions on the ability of local banks to diversify risks. Hence, even transitory deflationary shocks disturb the balance sheets of both borrowers and lenders and can have persistent real effects through fluctuations in credit availability.

When loans are made with imperfect information on the part of the lender, the availability of credit necessary to finance operations depends on the health of local financial intermediaries, on farmers' cash flow, and on the collateral available to secure loans. Reduction in available credit due to increased borrower leverage, reduced cash flow, and increased bank vulnerability have amplified the recent shocks to agriculture. As a result, relatively efficient farm producers may find themselves going bankrupt, reducing investment and maintenance expenditures, or selling out to farmers or land speculators with greater access to loanable funds.

The current economic upheaval in the U.S. farm sector raises important questions about public expenditures on domestic agriculture. While there is general agreement that current agricultural programs-farm credit and commodity programs dating from the 1930s-are poorly suited to addressing the problems of the 1980s, there is much less consensus about which new policy directions are likely to be the most efficient. A survey of the nation's agricultural credit markets suggests reforms that should be considered in the public debate.

The paper is organized as follows. To put the current farm situation in perspective, we review briefly postwar U.S. agricultural market conditions. Next we discuss the effects of credit supply restrictions on farm production. In our empirical work, we examine a panel data base from farm income statements and balance sheets at the state level covering approximately the last decade. We find economically significant effects of changes in collateral value, debt service burdens, and the availability of commercial bank credit on farm output.

The importance of local customer relationships in farm lending suggests roles for government intervention. To provide a framework for realistic policy analysis, we review recent developments in commercial 
banks, the Farm Credit System, and the Farmers Home Administration, three major lenders. Our empirical findings suggest reforms of current government intervention in agricultural credit markets and proposals for promoting more extensive diversification of farm bank loan portfolios. The reforms imply a shift away from the current emphasis on agricultural price and incomes programs.

\section{A Review of U.S. Postwar Agricultural Conditions}

Productivity growth in U.S. agriculture over the postwar period has been phenomenal. From 1955 to 1984 the U.S. Department of Agriculture measure of total output per hour of farm labor increased fivefold, and average crop production per acre has increased 75 percent. At the same time, fluctuations in income have been substantial.

Postwar economic conditions of U.S. agriculture can conveniently be divided into three distinct periods. ${ }^{3}$ The 1950 s and 1960 s were years of growing real farm incomes, although this growth lagged well behind that of overall U.S. economic activity. During the 1970s the relative decline was reversed, with rising commodity prices and sharply expanded exports leading to increasing farm incomes. Farmers expanded production, taking on substantial new debt to finance the expansion. Finally, during the 1980s farm prices declined, and, as the dollar appreciated, exports fell sharply. Farm incomes, and with them farmland values, fell at rates unprecedented in the postwar period. The drop in

3. For reviews of problems of financial distress in U.S. agriculture during the interwar period, see Lee Alston and Albert Hart. Alston in particular notes a pattern similar to that experienced in recent years. An agricultural boom in cash crops occurred after World War $\mathrm{I}$, accompanied by a large increase in mortgage debt to finance expansion. Land values fell subsequently in the mid-1920s and 1930s as expectations changed. The combination of high levels of debt service and restrictions of credit to agricultural borrowers led to the highest levels of foreclosure rates ever experienced in U.S. agriculture. Indeed, James Stock argues that high leveraging, heavy debt service burdens, and the associated risk of foreclosure were central to the agrarian unrest movements before World War I. Lee J. Alston, "Farm Foreclosures in the United States during the Interwar Period," Journal of Economic History, vol. 43 (December 1983), pp. 885-903; Albert G. Hart, Debts and Recovery: A Study of Changes in the Internal Debt Structure from 1929 to 1937 and a Program for the Future (New York: Twentieth Century Fund, 1938); James H. Stock, "Real Estate Mortgages, Foreclosures, and Midwestern Agrarian Unrest, 1865-1920," Journal of Economic History, vol. 43 (March 1984), pp. 89-105. 
income, coupled with the high levels of debt acquired during the expansion of the 1970s, has led to a sharp decline in the ability of farmers to meet their debt obligations and to the corresponding rise in farm bank failures.

These patterns are illustrated in tables 1 and 2 , which contain selected series describing farm income and the balance sheet of the farm sector. Relative to aggregate economic activity, farming has been on the decline throughout the postwar period. The decline was slow but steady through the 1950s and 1960s. In 1954, agricultural income was 9.2 percent of GNP; by 1970 , the fraction had dropped to 5.8 percent. Over the same period, farm income increased by only 0.6 percent annually. With the exception of 1958, between 1954 and 1970 the rate of return to assets in farming activities fluctuated between 1.0 and 6.3 percent.

The prolonged period of steady decline was reversed with the increase in farm exports and the rise in relative commodity prices during the 1970s. Between 1970 and 1979, real U.S. agricultural exports more than doubled, and real gross farm income rose at an annual rate of 4.1 percent. The return on farm assets and the value of farm equity rose, reflecting the improved market conditions. Nationally, real farm equity rose by 80 percent and real farmland values rose by 88 percent from 1971 to 1980 . The increases were most pronounced in the West and Middle West; between 1976 and 1980 alone, land values rose by 53 percent in Indiana, 49 percent in Minnesota, and 46 percent in Wisconsin and Iowa. ${ }^{4}$ Backed by this increased "paper value" of farmland, real farm debt rose by a total of 66 percent from 1971 to 1980 , compared with 57 percent from 1961 to 1970 . The ratio of farm debt to equity rose from an average of 0.13 for the 1950 s to an average of 0.21 for the 1970 s, reflecting sanguine expectations of growth in farm income.

The expansion halted abruptly in the 1980 s as interest rates rose, the dollar appreciated, and commodity prices fell. From 1979 to 1983, the agricultural sector suffered an absolute as well as a relative decline that was largely unanticipated by agricultural borrowers and lenders. The United States experienced a loss in market share in many crops during the 1980s. Farm income as a fraction of gross national product dropped from 5.5 percent in 1980 to 4.6 percent in 1984, and aggregate real farm

4. U.S. Department of Agriculture, Economic Research Service, "Farm Real Estate Market Developments: Outlook and Situation Report" (USDA, August 1984). 
Table 1. Farm Income, Borrowing, and Investment, 1950-84

Billions of 1984 dollars

\begin{tabular}{|c|c|c|c|c|c|c|}
\hline \multirow[b]{2}{*}{ Year } & \multirow{2}{*}{$\begin{array}{c}\text { Gross } \\
\text { income }\end{array}$} & \multirow{2}{*}{$\begin{array}{l}\text { Total } \\
\text { return } \\
\text { from }^{\text {assets }}\end{array}$} & \multirow{2}{*}{$\begin{array}{c}\text { Net } \\
\text { borrowing }\end{array}$} & \multirow{2}{*}{$\begin{array}{c}\text { Interest } \\
\text { on } \\
\text { debt }\end{array}$} & \multicolumn{2}{|c|}{ Capital expenditure } \\
\hline & & & & & Buildings & Machinery \\
\hline 1950 & 123.7 & 46.7 & 5.3 & 2.2 & 3.4 & 12.2 \\
\hline 1951 & 134.5 & 42.5 & 6.0 & 2.4 & 3.4 & 12.1 \\
\hline 1952 & 129.0 & -10.8 & 2.7 & 2.6 & 3.4 & 10.5 \\
\hline 1953 & 114.9 & -14.6 & -1.3 & 2.5 & 3.2 & 11.2 \\
\hline 1954 & 113.2 & 14.1 & 2.8 & 2.6 & 3.0 & 9.5 \\
\hline 1955 & 109.4 & 13.7 & 4.7 & 2.7 & 2.9 & 9.5 \\
\hline 1956 & 109.1 & 25.5 & 2.6 & 2.9 & 2.9 & 8.1 \\
\hline 1957 & 108.1 & 19.2 & 4.3 & 3.0 & 2.8 & 8.2 \\
\hline 1958 & 119.0 & 49.0 & 5.9 & 3.2 & 2.7 & 10.0 \\
\hline 1959 & 112.8 & 5.5 & 7.1 & 3.6 & 3.5 & 10.7 \\
\hline 1960 & 113.6 & 6.8 & 3.4 & 3.9 & 3.7 & 8.6 \\
\hline 1961 & 117.3 & 28.5 & 5.1 & 4.1 & 3.5 & 8.7 \\
\hline 1962 & 120.7 & 20.4 & 7.6 & 4.4 & 3.8 & 9.5 \\
\hline 1963 & 121.7 & 22.9 & 8.4 & 4.9 & 3.9 & 10.4 \\
\hline 1964 & 116.5 & 24.2 & 7.8 & 5.2 & 3.9 & 11.0 \\
\hline 1965 & 126.5 & 38.8 & 10.5 & 5.7 & 4.0 & 11.9 \\
\hline 1966 & 133.6 & 28.6 & 9.3 & 6.1 & 4.1 & 12.8 \\
\hline 1967 & 130.0 & 17.8 & 8.0 & 6.7 & 4.6 & 13.9 \\
\hline 1968 & 128.3 & 10.2 & 4.3 & 6.9 & 4.2 & 11.9 \\
\hline 1969 & 133.6 & 7.2 & 6.1 & 7.2 & 4.2 & 11.3 \\
\hline 1970 & 133.0 & 8.2 & 5.6 & 7.6 & 4.5 & 11.7 \\
\hline 1971 & 134.6 & 36.3 & 10.1 & 7.7 & 4.4 & 11.1 \\
\hline 1972 & 149.3 & 83.3 & 11.9 & 8.1 & 3.9 & 12.6 \\
\hline 1973 & 198.3 & 146.9 & 18.7 & 9.2 & 5.3 & 16.0 \\
\hline 1974 & 177.3 & 35.9 & 15.7 & 10.3 & 6.2 & 15.5 \\
\hline 1975 & 167.9 & 94.5 & 16.2 & 10.7 & 6.6 & 15.2 \\
\hline 1976 & 162.3 & 109.8 & 18.5 & 11.7 & 6.6 & 16.7 \\
\hline 1977 & 160.9 & 57.6 & 22.9 & 12.9 & 7.0 & 16.8 \\
\hline 1978 & 176.5 & 120.7 & 23.5 & 14.5 & 7.7 & 18.8 \\
\hline 1979 & 191.6 & 87.9 & 32.4 & 17.0 & 7.6 & 19.4 \\
\hline 1980 & 171.4 & 10.6 & 18.8 & 19.3 & 6.4 & 15.7 \\
\hline 1981 & 176.4 & -61.4 & 17.7 & 21.7 & 5.3 & 13.8 \\
\hline 1982 & 159.4 & -59.9 & 7.8 & 22.8 & 4.0 & 10.5 \\
\hline 1983 & 143.5 & -23.2 & 3.4 & 21.0 & 3.4 & 10.1 \\
\hline 1984 & 161.8 & -96.3 & -1.4 & 21.5 & 3.0 & 9.5 \\
\hline
\end{tabular}

Source: Emanuel Melichar, Agricultural Finance Databook (Board of Governors of the Federal Reserve System, Division of Research and Statistics, July 1985), tables 112 and 122.

a. Includes capital gains (or losses) on assets. 
Table 2. Synopsis of Farm Sector Balance Sheet and Rates of Return, 1950-84

Billions of 1984 dollars unless otherwise indicated

\begin{tabular}{|c|c|c|c|c|c|}
\hline \multirow[b]{2}{*}{ Year } & \multicolumn{3}{|c|}{ Farm balance sheet } & \multirow{2}{*}{$\begin{array}{l}\text { Total rate } \\
\text { of return } \\
\text { to assets } \\
\text { (percent) }^{\mathrm{a}}\end{array}$} & \multirow{2}{*}{$\begin{array}{l}\text { Total rate } \\
\text { of return } \\
\text { to equity } \\
\text { (percent) }^{\mathrm{a}}\end{array}$} \\
\hline & Assets & Debt & Equity & & \\
\hline 1950 & 445.5 & 44.3 & 401.1 & 10.5 & 11.7 \\
\hline 1951 & 473.1 & 45.1 & 428.0 & 9.0 & 9.8 \\
\hline 1952 & 482.5 & 49.0 & 433.5 & -2.2 & -2.9 \\
\hline 1953 & 463.5 & 51.9 & 411.6 & -3.2 & -4.0 \\
\hline 1954 & 460.3 & 54.1 & 406.3 & 3.1 & 2.9 \\
\hline 1955 & 467.3 & 56.3 & 410.9 & 2.9 & 2.9 \\
\hline 1956 & 478.0 & 57.8 & 420.2 & 5.3 & 5.8 \\
\hline 1957 & 489.0 & 58.3 & 430.7 & 3.9 & 4.2 \\
\hline 1958 & 517.2 & 63.6 & 453.5 & 9.5 & 10.3 \\
\hline 1959 & 535.9 & 68.7 & 467.2 & 1.0 & 0.7 \\
\hline 1960 & 533.2 & 70.9 & 462.3 & 1.3 & 0.9 \\
\hline 1961 & 543.1 & 75.5 & 467.6 & 5.2 & 5.3 \\
\hline 1962 & 558.8 & 81.7 & 477.1 & 3.7 & 3.6 \\
\hline 1963 & 573.4 & 88.5 & 484.9 & 4.0 & 4.0 \\
\hline 1964 & 587.4 & 94.5 & 492.8 & 4.1 & 4.1 \\
\hline 1965 & 611.3 & 101.3 & 510.1 & 6.3 & 6.9 \\
\hline 1966 & 634.4 & 107.7 & 526.7 & 4.5 & 4.8 \\
\hline 1967 & 652.4 & 113.6 & 538.8 & 2.7 & 2.7 \\
\hline 1968 & 660.8 & 117.3 & 543.5 & 1.5 & 1.5 \\
\hline 1969 & 663.3 & 119.0 & 544.3 & 1.1 & 1.0 \\
\hline 1970 & 658.9 & 118.5 & 540.4 & 1.2 & 1.0 \\
\hline 1971 & 668.8 & 120.9 & 548.0 & 5.4 & 6.0 \\
\hline 1972 & 714.0 & 127.4 & 586.7 & 11.7 & 13.6 \\
\hline 1973 & 798.8 & 133.9 & 664.9 & 18.4 & 22.2 \\
\hline 1974 & 822.1 & 136.5 & 685.7 & 4.4 & 5.6 \\
\hline 1975 & 844.2 & 141.8 & 702.4 & 11.2 & 13.0 \\
\hline 1976 & 927.4 & 152.5 & 774.9 & 11.8 & 13.6 \\
\hline 1977 & 993.0 & 167.7 & 825.3 & 5.8 & 6.5 \\
\hline 1978 & $1,071.8$ & 182.5 & 889.3 & 11.3 & 13.5 \\
\hline 1979 & $1,159.9$ & 194.8 & 965.2 & 7.6 & 9.1 \\
\hline 1980 & $1,185.6$ & 200.5 & 985.1 & 0.9 & 1.0 \\
\hline 1981 & $1,140.6$ & 203.7 & 936.9 & -5.4 & -7.4 \\
\hline 1982 & $1,065.0$ & 210.0 & 854.9 & -5.6 & -8.6 \\
\hline 1983 & $1,002.1$ & 209.6 & 792.5 & -2.3 & -4.7 \\
\hline 1984 & 911.9 & 200.7 & 711.2 & -10.6 & -15.7 \\
\hline
\end{tabular}

Source: Melichar, Agricultural Finance Databook, table 101.

a. The total rate of return is the sum of the income rate of return and real capital gains. 
income fell. The previous trend of increasing equity values also reversed as land prices fell; real national farm equity in 1984 was only 72 percent of its peak in $1980 .{ }^{5}$ With the fall in farm income and equity values came increased payments on the debt accrued during the 1970s and the lowest levels of investment in buildings and machinery since the early $1960 \mathrm{~s}$.

\section{CHANGING VOLATILITY OF FARM INCOMES}

Throughout the postwar period farm income has been volatile. That volatility increased, however, during the 1970 s and 1980 s, as summarized in the first four columns of table 3, which show the standard deviation of annual growth rates of farm income almost tripling, from 4.5 percent to 12.1 percent, from 1954-72 to 1973-84. As a comparison, the standard deyiations of the growth rate in real national income were 2.8 percent for 1954-72 and 3.8 percent for 1973-84, respectively.

The increased volatility of farm income since 1973 has also been associated with an increase in the correlation of agricultural income and U.S. aggregate economic conditions, as reflected in the regressions reported in the remaining four columns of table 3 . When the growth rate in farm income is regressed against the contemporaneous and lagged values of the growth rates of various income aggregates, two features of the changing relationship between movements in farm incomes and in various economic aggregates are evident. First, while the multiple correlation between farm income and lags of national income was only 3 percent for 1954-72, after 1973 it rose to 55 percent. Second, fluctuations in the various aggregates were associated with very different changes in farm incomes in the two periods. For example, in the early period, the cumulative change in real farm income associated with a 1 percent change in real national income was only 0.27 percent; in the later period the change was about 3 percent.

5. In addition to reflecting the decline in the relative price of agricultural commodities, the decline in farmland values in the 1980 s may well have been exacerbated by the general reduction in inflation. For example, Martin Feldstein has shown that the relative price of land (and of other nondepreciating real stores of value) will increase with inflation in the presence of unindexed taxes on capital income. Martin Feldstein, "Inflation, Tax Rules, and the Prices of Land and Gold,' Journal of Public Economics, vol. 14 (December 1980), pp. 309-18. 
As has been discussed extensively elsewhere, the changing relationships elaborated above reflect an increased importance of world trade and of the exchange rate in determining domestic commodity prices and therefore farm incomes. Indeed, while farm exports constituted only 14.5 percent of U.S. agricultural cash receipts in 1970, the fraction had jumped to 29.5 percent by 1980 . To the extent that the United States continues to compete in international agricultural markets, the increased sensitivity of agricultural incomes to world economic fluctuations seems likely to persist.

In years past, prices received by farmers were relatively stable, and agricultural income risk was likely to be uncorrelated with risk in other major sectors in the economy. Weather was usually the dominant source of fluctuations in farm output. The increasing risks faced by farmers today would not be of critical importance if farmers were able to diversify risk by holding part of their net worth in assets whose returns perform differently given fluctuations in interest rates and exchange rates. Unfortunately, however, farmers' wealth is held almost exclusively in farm-specific capital, such as farmland. Individual farmers are thus bearing more significant risks of income fluctuations than ever before. ${ }^{6}$ Given the increasing potential costliness of concentrating wealth in farmland, it remains to be explained why farmers chose to do so. We argue below that agency considerations provide a motivation for linking farm operation and ownership.

\section{PUBLIC POLICIES TOWARD AGRICULTURE}

Federal support for agriculture has taken two principal forms over the past fifty years: commodity programs and credit market programs. In recent years the commodity programs have become so expensiveand have apparently been so ineffectual-as to warrant a greater reliance on the credit market programs, which we discuss at greater length shortly.

6. The analysis follows the general discussion of the allocation of risk by William Brainard and F. T. Dolbear. We emphasize that farmers rely heavily on localized loan markets, often with limited potential for diversification, largely because of branching restrictions on commercial banks. William Brainard and F. T. Dolbear, "Social Risk and Financial Markets," American Economic Review, vol. 61 (May 1971, Papers and Proceedings, 1970), pp. 360-70. 


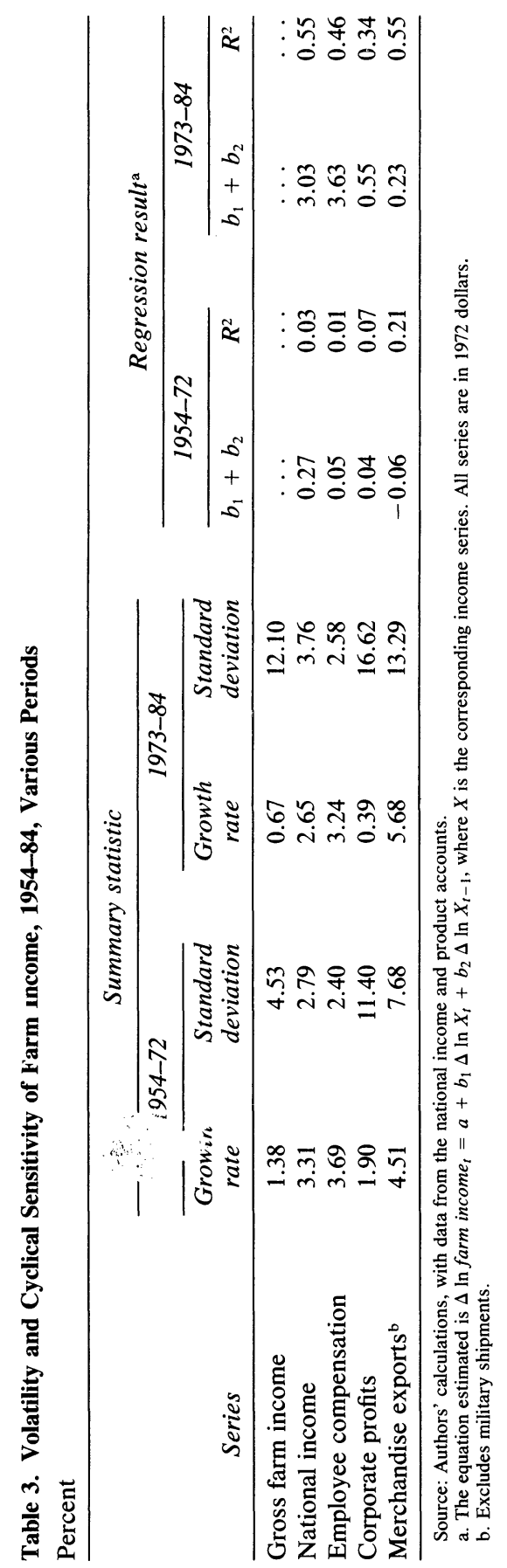


The foundation of federal farm commodity programs has been price supports and concomitant acreage-reduction efforts. The latter were implemented through a set of incentive programs put in place in the 1960 s, by which time it had become clear that, since the support price was effectively a floor price, farmers who chose not to reduce their acreage reaped the benefit of both higher production and higher prices. Nevertheless, the support and acreage-reduction programs were not overly costly in the 1970s, a period of rapid expansion and market price increases.

By the 1980s, world farm prices had declined, and more farmers were choosing to participate in government commodity programs. The budgetary costs grew as agricultural productive capacity expanded abroad, particularly in grains in Argentina and the European Economic Community. The 1981 farm bill, predicted to cost $\$ 11$ billion over the ensuing four years, actually cost $\$ 63$ billion. The Reagan administration's 1983 Payment-In-Kind program attempted large acreage reductions at a cost of $\$ 30,000$ per commercial farm in $1983 .{ }^{7}$ Expenditures on price supports and acreage-reduction programs in 1986 are projected to amount to between $\$ 26$ billion and $\$ 30$ billion-a per-farmer average of between $\$ 11,000$ and $\$ 12,500 . .^{8}$ Discussions of "bailouts" have figured prominently in 1985 and 1986 legislative efforts.

We argue below that the cost to the government of aiding farmers through improvements in agricultural credit market conditions compares favorably with the cost of commodity programs.

\section{Agricultural Credit Markets and Farm Production}

It is our contention that the crisis in agricultural credit markets is not merely a symptom of the recent adverse shocks farmers have suffered, but a means by which exogenous adverse shocks are worsened. The availability of credit per se provides an additional influence on agricultural income and investment.

7. See David H. Harrington and Alden C. Manchester, "Profile of the U.S. Farm Sector," Agricultural-Food Policy Review (USDA, 1985), pp. 25-53.

8. For a recent review of U.S. agricultural policies, see Elmer W. Learn, Philip L. Martin, and Alex F. McCalla, "American Farm Subsidies: A Bumper Crop," The Public Interest, no. 84 (Summer 1986), pp. 66-78. 
To motivate empirical work that addresses these questions, we begin with a simple model of links between credit markets and farm output. Suppose that domestic farm output, $Q^{s}$, is determined according to a production function defined over a set of inputs (chosen before production takes place) and is subject to random disturbances, such as the weather. The associated derived demands for inputs and financing depend on expected returns on investment, $R$ (that is, expected prices and yields), and on the shadow price of funds, $i^{s} .{ }^{9}$ Individual farmers invest until the expected return on the margin just equals the shadow price of funds.

The shadow price of funds involves much more than the loan interest rate; even casual observation of existing loan contracts reveals the importance of requirements for collateral, debt service, and other "nonprice" covenants. Three restrictions on credit availability are of particular relevance here: the importance of collateral and projected cash flow for obtaining loans and the attendant problems associated with reductions in the value of collateral, agency problems limiting the ability of individual farmers to raise new capital externally, and problems of credit rationing given lenders' imperfect information about borrowers' conditions. ${ }^{10}$ We discuss these in turn below; they certainly need not be mutually exclusive.

Collateral requirements provide a way for lenders to overcome their limited information about the ability of individual farmers to pay back loans. Lenders will receive either the total repaid principal plus interest or, if the farmer defaults, the value of the collateral plus any additional recoverable cash flow. That is, lenders can be thought of as maximizing

9. We implicitly assume that all investment is financed by debt. Later we discuss potential agency problems with equity finance. See Ben S. Bernanke and Mark Gertler, "Financial Efficiency, Collateral, and Business Fluctuations"' (Princeton University, 1986); Bruce C. Greenwald and Joseph Stiglitz, "Information, Finance Constraints, and Business Fluctuations"' (Princeton University, 1986).

10. These credit market imperfections are likely to apply to many types of small businesses. There are reasons, however, to believe that they may be relatively more severe for farmers. First, farmers are subject to much greater income volatility than the typical proprietor. Second, the production process in agriculture is capital(land)-intensive, and the minimum investment required is much larger than that for a typical small business with similar sales. Third, the nature of the production process works against farmers with respect to cash flow: there is a long period between the purchase of inputs and the sale of output, and short-run variable costs are a small portion of total costs. 
their gross return, $\rho$, which is related to the loan interest rate, $r$, according to

$$
\rho=\min [R+C,(1+r) L],
$$

where $L$ is the loan amount and $C$ is the borrower's collateral. Deterioration of borrowers' collateral or in the projected ability to service existing debts out of current cash flow exacerbates the information problems in the loan market, as discussed later. Were collateral substantial enough, it might be possible to approximate loan contracts equivalent to those that could be written were the lenders fully informed, since only low-risk borrowers-those confident of not losing their collateralwould seek loans.

Farmers' collateral is composed largely of an industry-specific asset, farmland, fluctuations in the value of which are highly positively correlated with realizations of returns on farming projects. The risk of default is thus more substantial than in cases where the value of collateral is fixed and independent of project returns. ${ }^{11}$ Hence the ability to service debt out of projected cash flow is an important additional consideration for the lender. Cash flow also influences credit availability through individual farmers who lend surplus cash to neighbors and relatives. When farmers have no surplus cash, the supply of private intermediation capital, which accounted for 34 percent of total farm debt in 1984, naturally drops.

The relevance of collateral and cash flow is also evident from the criteria that lenders actually use in deciding upon loans. For example, until 1971 Federal Land Banks could lend no more than 50 percent of the market value of real estate for which the loan was taken. When, in 1971, the limit was increased to 85 percent, member banks, recognizing that lending up to the limit was risky, increased their emphasis on the cash flow of the applicant. ${ }^{12}$ In addition, cash-flow analysis and real estate appraisal have always figured prominently in the loan supply

11. This argument relates well to discussions of "debt-deflation" episodes, in which wealth is redistributed from entrepreneurs to savers, with associated declines in the ability to obtain loans to finance productive investments. See Irving Fisher, "The Debt-Deflation Theory of Great Depressions," Econometrica, vol. 1 (October 1933), pp. 337-57; Bernanke, "Nonmonetary Effects"; Calomiris and Hubbard, "Price Flexibility."

12. Personal communication, James M. Schurr, Senior Vice President, Credit Standards, Farm Credit Corporation of America. 
decisions of commercial banks and in the Farmers Home Administration's evaluation of a potential borrower's "Farm and Home Plan."

The second restriction on credit availability involves "agency" problems. For credit restrictions to individual borrowers to have aggregate real effects, it must be the case that individual projects are imperfect substitutes for each other. There are several channels through which a lack of farm credit could have these aggregate effects. When farms suffer foreclosure and are not brought back into operation-or, even more dramatically, when farms are put up for sale and standing crops are not harvested-an aggregate drop in planted acreage and production results. More subtly, a lack of credit can lower productivity by forcing the sale of farm equipment, by reducing maintenance in building and equipment, by reducing fertilizer or seed qualities, or by forcing shifts to suboptimal crop or feed mixes to reduce operating expenses. Each of these channels results in output losses on specific farms. Since the farmland can be farmed at any one time by only a single operator, credit restrictions can in theory result in aggregate reductions in output.

Because of the complexity of modern farming operations, it can be difficult for outside parties to monitor these and similar subtle changes in production. When farm ownership is dissociated from farm management, losses of efficiency can thus occur because of "agency" problems. ${ }^{13}$ Attempts to raise collateral levels by mergers of existing farm operations by owner-operators would not be useful so long as the farmers have similar debt-equity ratios. One possible alternative solution is to take on new equity from nonfarmers. Potential agency costs are the likely explanation of why this option is so seldom used. ${ }^{14}$

13. Given asymmetries of information, contractual arrangements between borrowers and lenders cannot produce the same level of mutual benefit as would have been possible with costless information or costless aligning of the incentives of the parties to perform. See the general discussion of agency considerations in Michael C. Jensen and William H. Meckling, "Theory of the Firm: Managerial Behavior, Agency Costs, and Ownership Structure," Journal of Financial Economics, vol. 3 (October 1976), pp. 305-60; Michael C. Jensen and William H. Meckling, "Rights and Production Functions: An Application to Labor-managed Firms and Codetermination," Journal of Business, vol. 52 (October 1979), pp. 464-506; Kenneth J. Arrow, "The Economics of Agency,"' in John W. Pratt and Richard J. Zeckhauser, eds., Principals and Agents: The Structure of Business (Harvard Business School Press, 1985), pp. 37-51.

14. For a general discussion of constraints on equity financing, see Bruce Greenwald, Joseph E. Stiglitz, and Andrew Weiss, "Informational Imperfections in the Capital Market and Macroeconomic Fluctuations,' American Economic Review, vol. 74 (May 1984, 
The third restriction on credit availability involves problems of information. Theoretical research involving models of loan markets in which information between borrowers and lenders is asymmetric has shown that the loan interest rate and the shadow price of credit are not equivalent. Agricultural projects are "information-intensive" investments to the extent that monitoring of projects, and associated treatment of the land, and returns is difficult. In these information-intensive credit markets, credit rationing to some borrowers is likely. ${ }^{15}$

In the simplest possible model, no information problems exist, and the competitive equilibrium involves the agricultural credit markets clearing through adjustments in the rate of interest. However, when agricultural borrowers have private information about their project returns, lenders cannot distinguish the riskiness of individual projects, so that adverse selection will lead to credit rationing in a credit market equilibrium in which loan contracts specify only the interest rate. ${ }^{16}$ With a nonzero probability of default, lenders consider the potential for loan repayment as well as the interest rate to be charged when assessing the profitability of a loan. Past some critical level of the interest rate, highquality borrowers will either seek loanable funds elsewhere or leave the

Papers and Proceedings, 1983), pp. 194-200; Stewart C. Myers and Nicholas S. Majluf, "Corporate Financing and Investment Decisions When Firms Have Information That Investors Do Not Have," Journal of Financial Economics, vol. 13 (June 1984), pp. 187221. Tenure arrangements separating land ownership from farm operations can also discourage soil conservation (reducing future output) through short-term leases or inequitable sharing of the costs and benefits of conservation investments. See Sigfried von Ciriacy-Wantrup, Resource Conservation Economics and Policies (University of California Press, 1963); Linda K. Lee and William H. Stewart, "Landownership and the Adoption of Minimum Tillage," American Journal of Agricultural Economics, vol. 65 (May 1983), pp. 256-64.

15. See, for example, Dwight M. Jaffee and Thomas Russell, "Imperfect Information, Uncertainty, and Credit Rationing," Quarterly Journal of Economics, vol. 90 (November 1976), pp. 651-66; Joseph E. Stiglitz and Andrew Weiss, "Credit Rationing in Markets with Imperfect Information,” American Economic Review, vol. 71 (June 1981), pp. 393410; Bernanke, "Nonmonetary Effects"; N. Gregory Mankiw, "The Allocation of Credit and Financial Collapse," Quarterly Journal of Economics, vol. 101 (August 1986), pp. 455-70; Charles W. Calomiris and R. Glenn Hubbard, "Imperfect Information, Multiple Loan Markets, and 'Credit Rationing' "' (Northwestern University, 1986).

16. An important contribution of Stiglitz and Weiss is that imperfect information can limit the number of loans a "bank" will make; that is, "credit rationing" occurs in the sense that, within a class of observationally equivalent borrowers, not all receive loans. Stiglitz and Weiss, "Credit Rationing." 
credit market. As a result, banks charging high interest rates will find themselves with a preponderance of borrowers who have a high probability of default.

A corollary to these arguments for capital market imperfections is that changes in the ability of lenders specializing in monitoring information-intensive projects-here, commercial banks-to supply credit can have real effects. Agricultural banks are especially subject to such changes, for two reasons. First, state limitations on branch banking impede loan diversification, making farm banks particularly vulnerable to changes in local conditions. Second, as a recent evaluation of farm bank failures by Gregory Gajewski notes, banks taking over failed banks tend to be more conservative than average, making a smaller proportion of funds available for loans. ${ }^{17}$ Furthermore, the Federal Deposit Insurance Corporation (FDIC) has had difficulty finding suitable banks willing to take over failed rural banks. While it failed to obtain an acceptable bid to take over failed banks, and therefore used the "payoff" method of liquidation, in only 33 out of 239 bank failures from 1983 to 1985 , fully 24 such closings were in rural banks concentrated in such agricultural states as Kansas, Nebraska, Oklahoma, and Texas.

From the perspective of credit supply constraints these failures are particularly worrisome since local commercial banks have specialized in making and monitoring information-intensive loans and exploiting their customer relationships; the recent increase in bank failures is likely to disrupt the availability of credit to farmers. In addition, deterioration of the portfolios of surviving commercial banks, FCS intermediaries, and the Farmers Home Administration is likely to lead to greater conservatism of lenders.

Based on these credit market imperfections, we emphasize four potentially important components of the shadow price of credit to agricultural borrowers-the interest rate charged, $r$; the value of farm real estate, $R E$, as collateral; the projected debt service burden, $D S$, measured as the ratio of interest payments to cash receipts; and disruptions in the availability of information-intensive credit, measured by

17. Gregory Gajewski, "Rural Bank Failures: Not a Problem-So Far" (USDA, Economic Research Service, 1986). See also "Agricultural Conditions and the Prospects for Farm Banks," F.D.I.C. Banking and Economic Review, vol. 4 (March 1986), pp. 3-9. 
bank failures, FAILS. That is, the shadow price of funds in period $t-1$ is

$$
i_{t-1}^{s}=f\left(r_{t-1}, R E_{t-1},{ }_{t-1} D S_{t}, F A I L S_{t-1}\right) .
$$

The proper model, is, of course, for investment. As we do not have data on investment, we consider a reduced-form equation for farm output: ${ }^{18}$

$$
\begin{gathered}
Q_{t}^{s}=f\left(_{t-1} R_{t}, r_{t-1}, R E_{t-1},{ }_{t-1} D S_{t}, F A I L S_{t-1}\right), \\
(+) \quad(-) \quad(+) \quad(-) \quad(-)
\end{gathered}
$$

where ${ }_{t-1} R_{t}$ represents the expectation of $R_{t}$, the total return on the farm project, at time $t-1$ and where the predicted signs underscore the variables. ${ }^{19}$

\section{Empirical Evidence on Credit Supply Restrictions in U.S. Agriculture}

Macroeconomic time series data are not likely to be particularly useful for testing the impact of proxies for credit supply restrictions on farm output and income, because they cannot permit consideration of the large variation among farms in terms of crop mix (and hence expected crop prices), debt service capability, collateral, and situations in local credit markets. An alternative would be to examine microeconomic data on individual borrower-lender relationships over time. Although data on individual borrowers would permit estimation of microeconomic features of credit supply restrictions, they would not permit measuring directly the net aggregate effect of credit rationing on aggregate agricultural supply. As an intermediate step, we constructed a panel data base on farm income statements and balance sheets and commercial bank

18. There is evidence in the literature for credit effects on such long-term investments as soil conservation. We discuss this point later.

19. The ability of fluctuations in credit availability to affect producers' incomes depends, of course, on the sensitivity of total demand (including net foreign demand) to changes in price. Appreciation of the dollar and expansion of agricultural capacity abroad have made the total demand for U.S. farm goods substantially price-elastic. Reductions in farm output because of credit restrictions are thus likely to result in lower farm incomes. 
performance at the state level covering twenty-four states, including all of the principal agricultural states, from 1977 through $1984 .^{20}$ For complete documentation of data, see the appendix.

Observations consist of state-level totals or averages for a given year. For example, the real estate variable is the value of farmland in the state as of January 1 of the year in question. Given the data, we estimate equations of the form

$$
Q_{i t}^{s}=f\left(_{t-1} R_{i t}, r_{i t-1}, R E_{i t-1, t-1} D S_{i t}, F A I L S_{i t-1}, \bar{X}_{i}, \bar{Z}_{t}\right),
$$

where $i$ and $t$ denote the state and year, respectively, and $\bar{X}$ and $\bar{Z}$ denote a set of fixed state and time effects. The dependent variable used in the econometric work is a quantity index, constructed as the logarithm of the quotient of state cash receipts from marketing and a state-specific commodity price index.

No expected price term per se appears in our estimation of equation 4. Variables describing the demand for agricultural output will in general appear in any reduced-form equation. Rather than attempting to model annual aggregate demand shifts, we have included dummy variables for each year in our regression equations. Expected price changes are captured by the year dummies, which reflect changes in global aggregate economic activity, production, and the exchange rate, and by the state fixed effects, which capture state-level variation in the crop mix.

As we do not have data on farm interest rates state by state, no loan interest rate is included directly (because of the inclusion of the fixed time effects). Collateral is measured by the logarithm of constant-dollar real estate values, and debt service burdens are proxied by the ratio of interest payments to total cash flow, including government payments and nonfarm income. The bank failure measure is the total number of

20. The data used are not available before 1977. Our sample includes all states that were either among the top twenty states in total farm cash receipts in 1982, or among the top ten states in wheat cash receipts in 1982 , or both, with the exception of Florida, whose crop share changed sufficiently over the sample period to make the assumption of our fixed-effects model questionable. To this group we added South Dakota, leaving the following twenty-four states in our sample: Arkansas, California, Colorado, Georgia, Idaho, Illinois, Indiana, Iowa, Kansas, Kentucky, Michigan, Minnesota, Mississippi, Missouri, Montana, Nebraska, North Carolina, North Dakota, Ohio, Oklahoma, South Dakota, Texas, Washington, and Wisconsin. Because data on loan charge-offs were not available for North Carolina and Washington, the regressions involving this variable used only twenty-two states. 
bank failures in that state in that year. As another proxy for supply restrictions we include net loan charge-offs as a percentage of total loans at agricultural banks in that state in that year.

In addition to the specification in equation 4, we also considered various interactions with the debt service variable to test whether effects of debt service on credit availability vary according to initial leverage (as measured by the debt-equity ration, $D / E$ ), and whether given levels of debt service burdens are more severe for farms of moderate size, $F S$, than for large farms. For this second interaction, we define $F S$ as the fraction of output produced in each state by farms of moderate sizethose with total sales between $\$ 40,000$ and $\$ 100,000$ in 1982 . The farm size variable is a proxy for the distribution of debt burden within a particular state. Given that large farms tend to have higher-than-average debt-equity ratios, a high proportion of moderate-sized farms in a given state indicates a more even distribution of debt among farmers and hence less vulnerability in the aggregate to shocks that increase the debt-equity ratio.

Our estimation strategy is designed to avoid two potential pitfalls that would arise were one to use ordinary least squares in an attempt to identify the credit supply effects embodied in the theoretical relationship, equation 3. First, persistent differences from state to state in crop and livestock mixes, and thus in credit requirements as inputs to production functions, could lead to spurious significance of the credit variables; we avoid this potential problem by estimating the regressions using fixed state effects. Second, because of the obvious potential simultaneity of credit demand and the supply of output, we estimate our output equations using two-stage least squares. We use as instruments lagged endogenous variables and their interactions with survey responses of agricultural bankers indicating whether their expectations were for increased or decreased loan demand in the next quarter. ${ }^{21}$ The latter is designed to capture pure demand effects. Though not reported here, our results are robust to the use instead of lagged values of the independent variables.

Our two-stage least squares estimation results using fixed state and time effects appear in table 4 . The estimated regression coefficients and

21. We use an annual average of a quarterly time series of survey responses of agricultural bankers to indicate whether their expectations were for increased or decreased loan demand in the next quarter. The expectations data were taken from the Agricultural Credit Conditions Survey of the Federal Reserve Bank of Minneapolis. 


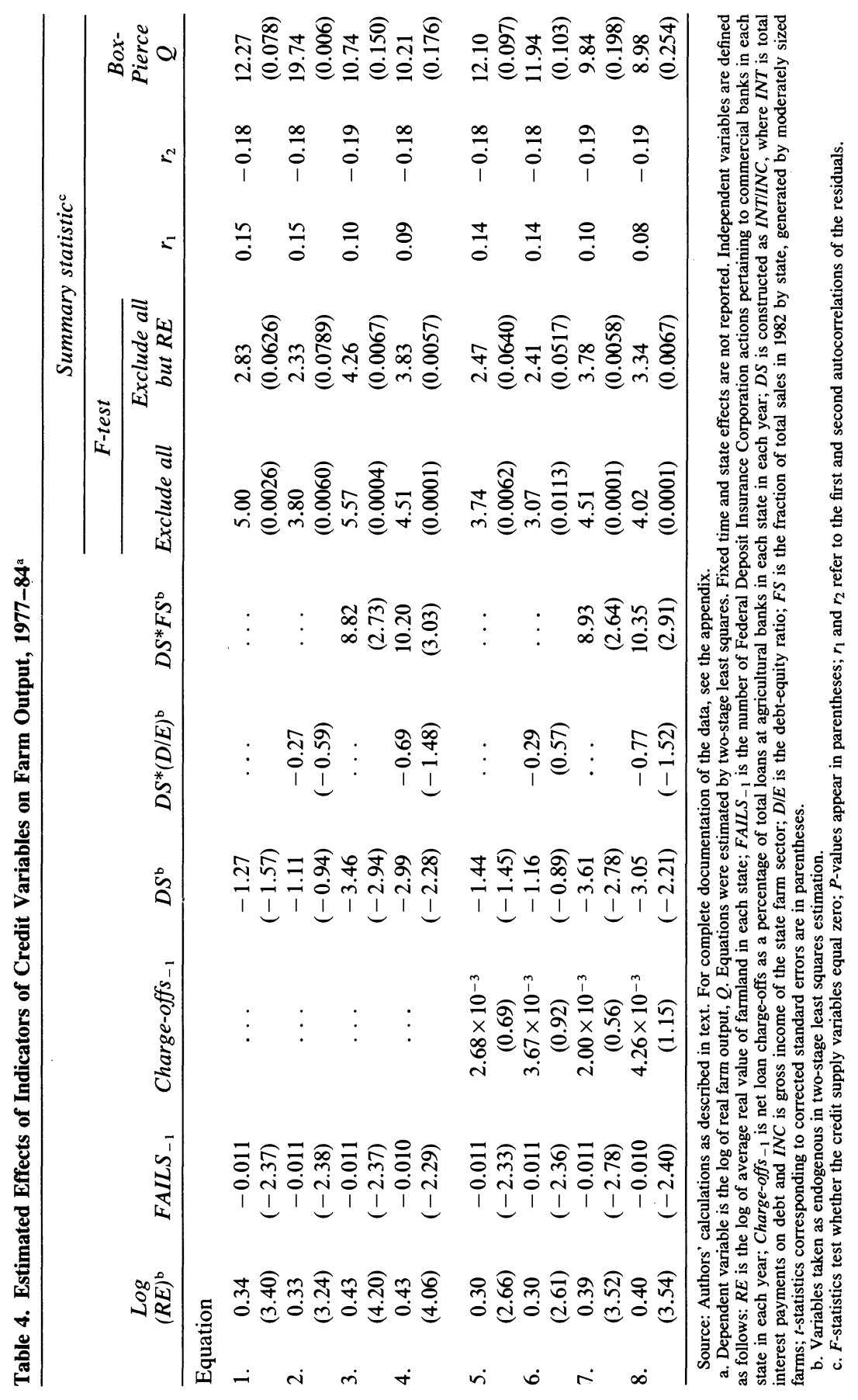


their $t$-statistics are reported in the first six columns. The seventh and eighth columns contain the $F$-statistics (and their $P$-values) for tests that the credit supply variables equal zero, and the final three columns contain measures of the serial correlation present in the residuals. The BoxPierce $Q$ statistics and the estimated serial correlation coefficients indicate slight but statistically significant serial correlation in the residuals, which is unsurprising since we omitted some variables, such as factor prices, either because they were unavailable or because they were not germane to this investigation. The reported standard errors have been adjusted to correct for this serial correlation. ${ }^{22}$

Several patterns in these results are of particular interest. The impact on output of changes in collateral values or in the local provision of information-intensive credit (as measured by real estate values and commercial bank failures, respectively) have the expected sign and are precisely estimated. Increases in debt service burdens (interest payments relative to cash receipts) are associated with reductions in output, though the coefficient is in some cases imprecisely measured. As one would expect, given levels of debt service burdens have a more substantial effect when debt-equity ratios are high, although this effect is not statistically significant. ${ }^{23}$

Local bank failures reduce output by restricting the available supply of credit; we discuss this point in more detail later in the context of regulatory restrictions on commercial bank lending. Estimated coefficients on the loan charge-offs measures are never statistically significantly different from zero, though their inclusion sharpens the precision of the estimates of the effects of the debt service variable. While the effect of bank failures may seem large at first glance, it is important to note that such failures are discrete proxies for many continuous and persistent changes such as in the quality of bank loan portfolios.

Debt service burdens have a less severe impact for medium-sized farms than for other farms. If credit constraints are less relevant for borrowers with "deep pockets" and if the large farms in our sample

22. The correction entailed estimating the mean temporal error covariance matrix for each state and then using this estimate to compute the adjusted coefficient covariance matrix.

23. Our results with respect to credit variables are robust to using constant-dollar cash receipts as the dependent variable and to including the state-specific relative prices of farm products as an additional regressor, although this price variable formally should not enter the reduced-form specification. 
became large because of higher-than-average leveraging, then, for a given statewide average debt service ratio, the more moderate-sized farms will have less binding credit constraints. This interpretation of the coefficient on $D S^{*} F S$ is consistent with the relatively high debt-equity ratios of large farms in the boom years of the 1970s presented in table 5 .

Issues of interpretation arise over any empirical results attempting to separate credit supply and demand effects. For example, in addition to serving as collateral, land values will tend to reflect market expectations of future farm cash flows, thus agricultural prices. ${ }^{24}$ If, however, prices for particular commodities are the same in all states, if expectations of prices are similar in all states, and if each state's crop mix is relatively stable from year to year, then, as argued above, fixed state and time effects will capture both expected prices and realized agricultural demand.

A possible confusion between supply and demand effects arises in the debt service measure, where high values of debt service may indicate sanguine expectations. Here, the demand-side effect leads one to expect a positive coefficient, which is opposite to the negative coefficient implied by the credit supply effect and the negative coefficients estimated by two-stage least squares reported in table 4.

Finally, there is independent evidence of credit supply restrictions on the part of commercial banks. Quarterly surveys of credit conditions at commercial banks by the regional Federal Reserve Banks in Chicago, Kansas City, Dallas, Minneapolis, and Richmond indicate a marked decline in 1982 in the number of banks reporting a "higher" availability of funds for new farm loans and a substantial increase in the percentage of banks reporting that more collateral would be required relative to loan size. ${ }^{25}$

An explanation for our empirical results that does not involve credit rationing is that declines in farm output result in bank failures and that farm output is serially correlated. According to that interpretation, the bank failures variable might spuriously be capturing this dependence on farm output. To check for this possibility, we examined the time series relationship between the credit variables and the output variable. In both

24. This long-run perspective must be qualified to the extent that liquidity constraints raise the discount rate for calculating the present value of land.

25. These data are summarized in Emanuel Melichar, Agricultural Finance Databook (Board of Governors of the Federal Reserve System, Division of Research and Statistics, July 1985). 
Table 5. Debt-Asset Ratios by Value of Sales Class, 1975-78

Percent

\begin{tabular}{lrrrr}
\hline Value of sales class in dollars & 1975 & 1976 & 1977 & 1978 \\
\hline Greater than 100,000 & 27.6 & 25.3 & 25.2 & 22.7 \\
$40,000-99,999$ & 18.5 & 17.6 & 18.1 & 19.8 \\
$20,000-39,999$ & 14.6 & 15.0 & 14.0 & 15.8 \\
$10,000-19,999$ & 9.6 & 11.9 & 12.2 & 14.8 \\
$5,000-9,999$ & 6.6 & 7.3 & 7.4 & 9.1 \\
$2,500-4,999$ & 7.6 & 5.5 & 5.6 & 9.0 \\
Less than 2,499 & 3.3 & 4.7 & 4.2 & 6.3 \\
All & 15.8 & 15.7 & 15.7 & 16.7 \\
\hline
\end{tabular}

Source: U.S. Department of Agriculture, Economic Research Service, Economic Indicators of the Farm Sector: National Financial Summary 1980 (GPO, 1981).

a bivariate model of bank failures and the logarithm of output and a trivariate model of bank failures, the logarithm of loan charge-offs, and the logarithm of output, the output variable failed to Granger-cause the banking variables at a 15 percent level. (Both models included state and time fixed effects.) In contrast, as expected, real farm income does Granger-cause bank failures at the 5 percent level in both the bivariate and trivariate models, although the link from farm income to loan chargeoffs is, somewhat surprisingly, weaker. Taken together, these results suggest that this alternative explanation will not explain the results in table 4 .

\section{Financial Variables and the Trend Toward Larger Farms}

An important characteristic of U.S. agriculture in the postwar period has been a trend toward larger and more productive farms. ${ }^{26}$ As table 6 shows, by 1984 U.S. farm size, as measured by real crop sales, had almost tripled since 1960, with the fastest growth occurring in the $1960 \mathrm{~s}$.

The literature on farm production suggests two reasons for increasing

26. Farm size statistics are conventionally reported in intervals of nominal dollars of sales (for example, the number of farms with sales between $\$ 20,000$ and $\$ 39,999$ ). We have deflated these nominal dollar values using the farm price index to compute selected farm size statistics in 1984 dollars. Distributions for aggregate sales and income were constructed from data on the number of farms with sales or income in various nominal ranges, which were deflated by the farm price index and then used to estimate lognormal distributions. Sales and income data are from USDA, Economic Research Service, Economic Indicators of the Farm Sector: National Financial Summary 1984 (GPO, 1986), tables 27 and 30. The farm price index is from the Economic Report of the President. 
Table 6. Trends in Real Sales per Farm, 1960-84a

\begin{tabular}{|c|c|c|c|c|c|c|}
\hline \multirow[b]{3}{*}{ Year } & \multirow{2}{*}{\multicolumn{3}{|c|}{$\begin{array}{c}\text { Distribution of } \\
\text { sales per farm } \\
\text { (thousands of } 1984 \text { dollars) }\end{array}$}} & \multicolumn{2}{|c|}{$\begin{array}{l}\text { Number of farms } \\
\text { (thousands) }\end{array}$} & \multirow{3}{*}{$\begin{array}{c}\text { Fraction } \\
\text { of } \\
\text { income } \\
\text { from } \\
\text { farms } \\
\text { with } \\
\text { sales of } \\
\$ 50,000 \\
\$ 150,000 \\
\text { (percent) }\end{array}$} \\
\hline & & & & \multirow[b]{2}{*}{ Total } & \multirow{2}{*}{$\begin{array}{c}\text { With } \\
\text { sales of } \\
\$ 50,000- \\
\$ 150,000\end{array}$} & \\
\hline & Mean & Median & $\begin{array}{l}\text { Ninetieth } \\
\text { percentile }\end{array}$ & & & \\
\hline 1960 & 22.7 & 7.8 & 51.5 & 3963 & 322 & 29.2 \\
\hline 1961 & 24.4 & 8.1 & 55.9 & 3825 & 334 & 29.3 \\
\hline 1962 & 25.8 & 8.2 & 60.1 & 3692 & 339 & 29.4 \\
\hline 1963 & 28.0 & 8.6 & 66.2 & 3572 & 351 & 29.7 \\
\hline 1964 & 29.2 & 8.9 & 69.2 & 3457 & 351 & 29.8 \\
\hline 1965 & 30.4 & 8.8 & 71.3 & 3356 & 344 & 29.3 \\
\hline 1966 & 32.2 & 8.7 & 73.8 & 3257 & 337 & 28.9 \\
\hline 1967 & 34.6 & 9.4 & 79.9 & 3162 & 347 & 28.7 \\
\hline 1968 & 35.9 & 9.4 & 81.9 & 3071 & 340 & 28.7 \\
\hline 1969 & 37.7 & 7.7 & 81.6 & 3000 & 304 & 25.2 \\
\hline 1970 & 39.5 & 7.8 & 84.8 & 2949 & 304 & 24.7 \\
\hline 1971 & 41.2 & 7.9 & 89.5 & 2902 & 304 & 24.3 \\
\hline 1972 & 43.7 & 7.9 & 93.2 & 2860 & 303 & 23.8 \\
\hline 1973 & 44.7 & 7.7 & 101.9 & 2823 & 300 & 24.4 \\
\hline 1974 & 45.0 & 7.8 & 104.9 & 2795 & 301 & 24.6 \\
\hline 1975 & 48.3 & 9.2 & 109.6 & 2521 & 293 & 24.8 \\
\hline 1976 & 51.1 & 9.6 & 115.2 & 2497 & 298 & 24.2 \\
\hline 1977 & 52.1 & 9.8 & 117.8 & 2456 & 296 & 24.1 \\
\hline 1978 & 55.8 & 10.3 & 124.7 & 2436 & 302 & 23.6 \\
\hline 1979 & 57.4 & 9.6 & 120.7 & 2432 & 291 & 23.7 \\
\hline 1980 & 59.2 & 9.8 & 127.7 & 2433 & 296 & 23.5 \\
\hline 1981 & 58.8 & 10.2 & 136.8 & 2434 & 302 & 23.5 \\
\hline 1982 & 63.6 & 11.4 & 156.5 & 2401 & 314 & 22.5 \\
\hline 1983 & 60.3 & 11.5 & 159.2 & 2370 & 311 & 22.7 \\
\hline 1984 & 61.0 & 11.6 & 159.5 & 2328 & 308 & 22.9 \\
\hline
\end{tabular}

Source: Authors' calculations using data from Economic Indicators of the Farm Sector: National Financial Summary 1984.

a. The mean is total real farm marketings divided by the number of farms. The median and ninetieth percentile point of distribution of farm sales, the number of farms with sales between $\$ 50,000$ and $\$ 150,000$ (in 1984 dollars), and the fraction of gross income generated by farms with sales between $\$ 50,000$ and $\$ 150,000$ were estimated assuming that sales per farm is lognormally distributed. All deflation was done using the farm price index from the Economic Report of the President, February 1986.

farm sizes. The most important is surely the tremendous increase in productivity in agriculture in terms of output per acre. Technological advances tend to increase the minimum scale for efficient farming operations, although the minimum scale necessarily varies with the crop mix. In a detailed review of studies on the minimum efficient scale for 
farming operations, Bruce Hall and Phillip Le Veen find that most of the studies suggest that the long-run average-cost curve is " $\mathrm{L}$-shaped," so that most of the benefits of technology are achieved by modestly sized farms of from 100 to 320 acres, depending on the crop. ${ }^{27}$ The studies suggest that very large farms have relatively small technological advantages over farms of moderate size. Several other authors have argued that the realization of managerial economies and economies of scope require moderate farm size. ${ }^{28}$

The second explanation for the increase in farm size is that farmers have different access to credit, depending on cash-flow histories and collateral, and that the farms of the "creditworthy expand disproportionately." Though Hall and Le Veen note that financial factors could lead to an increase in farm size, they do not present any empirical evidence on this point. Indirect evidence of the importance of access to credit for farm investment comes from the work of Linda Lee, who finds that large farms or farms with significant uncommitted cash flows were more active than others in soil-conservation practices. ${ }^{29}$ Credit constraints, in other words, may lead farmers to reduce long-run investments that would otherwise maintain the quantity or quality of the topsoil and land. ${ }^{30}$ One would expect credit supply effects to be especially pronounced for long-term investments such as soil conservation, since short-run credit supply restrictions increase the effective discount rates of constrained borrowers.

27. Bruce F. Hall and E. Phillip Le Veen, "Farm Size and Economic Efficiency: The Case of California," American Journal of Agricultural Economics, vol. 59 (November 1978), pp. 589-600. A study of cash grain farms in Illinois makes a similar finding. See Philip Garcia, Steven T. Sonka, and Man Sik Yoo, "Farm Size, Tenure, and Economic Efficiency in a Sample of Illinois Grain Farms," American Journal of Agricultural Economics, vol. 64 (February 1982), pp. 119-23. See also the earlier discussion in Kenneth R. Krause and Leonard R. Kyle, "Economic Factors Underlying the Incidence of Large Farming Units: The Current Situation and Probable Trends," American Journal of Agricultural Economics, vol. 52 (December 1970), pp. 748-63.

28. See, for example, the essays in Wes Jackson, Wendell Berry, and Bruce Coleman, eds., Meeting the Expectations of the Land: Essays in Sustainable Agriculture and Stewardship (North Point Press, 1984).

29. Linda K. Lee, "The Impact of Landownership Factors on Soil Conservation," American Journal of Agricultural Economics, vol. 62 (December 1980), pp. 1070-76.

30. A good discussion of the costs of poor soil conservation practices can be found in David Pimentel and others, "Land Degradation: Effects on Food and Energy Resources," Science, vol. 194 (October 8, 1976), pp. 149-55. In the 1930s, poor soil conservation practices were thought by life insurance company lending agents to accompany credit constraints for farmers; see the discussion in Archibald M. Woodruff, Jr., Farm Mortgage Loans of Life Insurance Companies (Yale University Press, 1937). 
Trying to model links between farm agglomeration and such credit variables as collateral, debt service ratios, or debt-equity ratios is problematic because of the multiplicity of potential relationships. Increased debt service and debt-equity ratios can lead to larger farms in various ways, and they can also lead to smaller farms. A farmer who expects either increased product demand or increased productivity will be tempted to expand his operation. Thus increased $D S$ and $D / E$ would be associated with increased expansion of output and of farm sizes, an explanation consistent with the expansion of output and debt in the 1970s. But as debt service and debt-equity ratios increase, more farmers are exposed to the risk of failure. If the failed farms are sold to already large and expanding enterprises, the effect of farm failures will be to increase average farm size. If they are subdivided and sold as smaller farms, average farm size will decrease.

While increasing average farm size may reflect the increasing productivity of all existing farmers, a widening of differences in farm size indicates differences in individual farmers' abilities or desires to make their farms grow, providing evidence consistent with the importance of credit availability. Table 6 shows that average farm size increased primarily because the largest farms expanded. The fraction of income of moderately sized farms-those with real sales between $\$ 50,000$ and $\$ 150,000$-fell from 1960 to 1984 . Over this period, while mean farm sales and the sales of the ninetieth percentile tripled, median farm sales grew by only 49 percent. Thus the increase in the average scale of production has not been accomplished through proportional increases in all farms' output; rather, the variance of farm size has increased dramatically along with the mean.

\section{Public Policy and Institutional Farm Lenders}

Establishing the importance of credit supply restrictions provides a starting point for policy analysis. It is important, however, to focus on the institutions of agricultural credit markets and how they might be used in the implementation of policy reforms. The principal postwar institutional farm lenders have been commercial banks, the Farm Credit System, the Farmers Home Administration, and life insurance companies. As table 7 shows, the importance of life insurance companies has 
Table 7. Total Outstanding Farm Debt by Lender, 1950-85

\begin{tabular}{|c|c|c|c|c|c|}
\hline \multirow[b]{2}{*}{ Year } & \multirow{2}{*}{$\begin{array}{c}\text { Total } \\
\text { (billions } \\
\text { of } 1984 \\
\text { dollars) }^{\mathrm{a}} \\
\end{array}$} & \multicolumn{4}{|c|}{ Holder of debt (percent) } \\
\hline & & Banks & $\begin{array}{c}\text { Life } \\
\text { insurance } \\
\text { companies }\end{array}$ & $\begin{array}{l}\text { Farm } \\
\text { Credit } \\
\text { System }\end{array}$ & $\begin{array}{c}\text { Farmers } \\
\text { Home } \\
\text { Administration }\end{array}$ \\
\hline 1950 & 22.4 & 50.2 & 18.2 & 22.8 & 8.8 \\
\hline 1951 & 24.2 & 51.9 & 18.5 & 21.5 & 8.2 \\
\hline 1952 & 27.1 & 53.5 & 18.4 & 20.9 & 7.2 \\
\hline 1953 & 28.2 & 52.0 & 19.3 & 21.0 & 7.6 \\
\hline 1954 & 27.5 & 48.0 & 21.9 & 21.6 & 8.5 \\
\hline 1955 & 29.0 & 47.5 & 22.2 & 21.6 & 8.7 \\
\hline 1956 & 31.8 & 47.7 & 22.1 & 22.1 & 8.1 \\
\hline 1957 & 32.6 & 45.1 & 22.9 & 23.7 & 8.3 \\
\hline 1958 & 34.9 & 44.6 & 21.9 & 25.1 & 8.4 \\
\hline 1959 & 37.9 & 45.6 & 20.5 & 26.1 & 7.8 \\
\hline 1960 & 42.0 & 46.2 & 19.4 & 27.0 & 7.4 \\
\hline 1961 & 43.8 & 45.4 & 19.4 & 27.8 & 7.5 \\
\hline 1962 & 46.7 & 44.1 & 19.0 & 28.2 & 8.7 \\
\hline 1963 & 51.2 & 44.9 & 18.4 & 27.9 & 8.8 \\
\hline 1964 & 55.9 & 45.2 & 18.5 & 27.7 & 8.6 \\
\hline 1965 & 60.5 & 44.0 & 19.2 & 28.1 & 8.6 \\
\hline 1966 & 65.4 & 43.1 & 19.3 & 28.8 & 8.9 \\
\hline 1967 & 71.2 & 42.5 & 18.8 & 30.0 & 8.6 \\
\hline 1968 & 75.3 & 42.1 & 18.1 & 31.2 & 8.6 \\
\hline 1969 & 77.1 & 41.7 & 17.7 & 31.9 & 8.8 \\
\hline 1970 & 79.1 & 41.1 & 16.7 & 33.5 & 8.7 \\
\hline 1971 & 80.8 & 41.2 & 15.3 & 34.9 & 8.6 \\
\hline 1972 & 85.2 & 42.2 & 13.8 & 35.8 & 8.2 \\
\hline 1973 & 89.2 & 43.4 & 12.6 & 36.1 & 7.9 \\
\hline 1974 & 94.1 & 44.1 & 11.5 & 37.1 & 7.3 \\
\hline 1975 & 98.3 & 41.9 & 10.8 & 40.3 & 7.1 \\
\hline 1976 & 104.8 & 40.6 & 10.2 & 41.6 & 7.6 \\
\hline 1977 & 111.6 & 40.8 & 9.9 & 42.1 & 7.2 \\
\hline 1978 & 118.9 & 39.6 & 10.3 & 41.9 & 8.1 \\
\hline 1979 & 125.0 & 38.0 & 10.7 & 41.5 & 9.8 \\
\hline 1980 & 135.0 & 34.3 & 10.4 & 42.0 & 13.3 \\
\hline 1981 & 137.6 & 31.5 & 10.0 & 44.0 & 14.4 \\
\hline 1982 & 144.1 & 29.2 & 9.1 & 46.2 & 15.5 \\
\hline 1983 & 144.9 & 30.1 & 8.5 & 46.1 & 15.2 \\
\hline 1984 & 143.1 & 31.8 & 8.3 & 44.9 & 15.0 \\
\hline 1985 & 140.0 & 32.5 & 8.0 & 43.7 & 15.8 \\
\hline
\end{tabular}

Source: Melichar, Agricultural Finance Databook.

a. Debt figures exclude loans made by "individuals and others." 
diminished steadily since the mid-1960s. ${ }^{31}$ We review the current status and special attributes of the other three lenders below. Each has particular characteristics that offer possibilities for federal intervention and reform.

\section{COMMERCIAL BANKS}

Commercial agricultural banks-banks with greater than the national average of 16 percent of their loan portfolio in agriculture-are concentrated in states where banking is restricted by prohibitions on interstate entry and, typically, by unit-banking laws. Branch-banking restrictions increase the already weakened banks' vulnerability to failure-by restricting bank size and the ability to diversify loan risks-and accentuate the consequences of bank failures by limiting the entry of alternative intermediaries. ${ }^{32}$ The high leverage and low cash flow of many agricultural borrowers indicate that private bank failures and concomitant agricultural bank credit scarcity are unlikely to abate over the next few years. ${ }^{33}$

The scope for improvement of agricultural banks through branching and diversification is demonstrated by the robust performance of California banks despite the weakness of the state's large farm economy.

31. The decline in life insurance companies' participation in agricultural credit markets (primarily in real estate mortgages) results in part from the increased involvement of the Farm Credit System in farm lending. This decline has intensified in recent years, as might be expected from an analysis of lenders' relative efficiency in monitoring informationintensive loans in bad times. Life insurance companies also sharply curtailed their lending in the 1930s in response to both the deflation in farm prices and the centralization of loan administration; see Woodruff, Farm Mortgage Loans.

32. Sixty-eight agricultural banks failed in 1985 , most of them small relative to surviving agricultural banks and nonagricultural banks. Failed agricultural banks had average total assets of $\$ 21$ million, which is two-thirds the average for agricultural bank assets and oneeighth the average size for all commercial banks. Vulnerable agricultural banks-those with past-due and nonperforming loans greater than total capital-rose from 240 at the end of 1984 to 332 at the end of 1985 . Net charge-offs as a percentage of total loans at agricultural banks increased from an average of 0.21 in the 1970 s to 0.32 in $1980,0.69$ in $1982,1.22$ in 1984 , and 2.12 in 1985. The rate of return on equity for agricultural banks as a group declined from an average of 14 percent in the 1970s to 11 percent in 1983, 9 percent in 1984, and 6 percent in 1985. See Emanuel Melichar, "Agricultural Banking Experience, 1985, Preliminary Data Appendix" (Board of Governors of the Federal Reserve System, March 8, 1986).

33. See Melichar, "Agricultural Banks," pp. 437-38. Melichar estimates that twofifths of farms' bank debt is in danger of default. 
California leads the country in total agricultural production and has had a higher-than-average percentage of troubled agricultural loans. The percentage of agricultural loans with nonaccrual status in 1984 was 8.4 for California and 4.7 for the rest of the country. The agricultural loan delinquency rate for 1984 was 13.1 percent in California, compared with the national average of 8.9 percent. Net charge-offs as a percentage of agricultural loans were 6.1 percent in California and 1.8 percent in other states. ${ }^{34}$ At the same time, California accounted for only one of the sixtyeight agricultural bank failures in 1985 . The reason that California's banks are weathering the storm is that most agricultural lending in the state comes from large banks, which hold only 3 percent of their portfolio in agricultural production loans. ${ }^{35}$

Further evidence of the scope for improvement through branch banking comes from the distribution of troubled banks. In 1985, more than one-third of U.S. agricultural banks had a proportion of nonperforming loans of less than 2 percent, compared with the national average of 4.5 percent. Just under a third had ratios in excess of 5 percent. Similarly, four out of ten agricultural banks showed a rate of return to equity of less than 5 percent, while five of ten showed a greater than 10 percent rate of return. ${ }^{36}$ Branch banking should lead to a more even distribution of losses on agricultural loans among banks and prevent as many banks from crossing the failure threshold. In addition, it would allow banks with a lower proportion of loan losses to enter markets occupied by troubled banks.

THE FARM CREDIT SYSTEM

The Cooperative Farm Credit System (FCS) is a nationwide network of financial institutions owned by borrower-stockholders and regulated by the Farm Credit Administration. It is divided into twelve districts and is comprised of twelve Federal Land Banks, twelve Federal Intermediate Credit Associations, twelve Banks for Cooperatives, and a central Bank for Cooperatives. The Federal Land Banks finance mortgages through more than 400 Federal Land Bank Associations; the Federal Interme-

34. Emanuel Melichar, "Agricultural Banking Experience, 1984" (Board of Governors of the Federal Reserve System, March 20, 1985), pp. 27, 40.

35. Melichar, "Agricultural Banks," p. 440.

36. Ibid., p. 447. 
diate Credit Associations finance production loans through nearly as many Production Credit Associations.

Until recently the FCS was a loose confederation of decentralized organizations with most discretionary authority in the hands of districtlevel management, though funds have been raised by the national-level Farm Credit Funding Corporation. One result of the current financial stress has been greater centralization in lending policy. The Farm Credit Amendments Act of 1985 authorized the existing Farm Credit Administration (FCA) to regulate the districts more closely and from a separate arm's-length position. The legislation also authorizes the new Farm Credit Capital Corporation to allocate funds among districts in order to shore up the relatively weak units with the surplus of the relatively strong units. The new Farm Credit Corporation of America is to act as a research and advisory arm of the FCS. ${ }^{37}$

The troubled condition of the FCS largely parallels that of commercial banks; both have roughly the same proportion of debtors in each cashflow-debt-equity class. ${ }^{38}$ Like commercial banks, FCS intermediaries have experienced a growing rate of loan delinquency and threats of default. Portfolio quality varies greatly among FCS districts. ${ }^{39}$ Through

37. The movement toward centralization corresponds to a commitment from Congress to allow the use of public funds to support the FCS, under a complex formula involving the participation of the Farm Credit Administration, the Secretary of the Treasury, and Congress. Thus at the same time Congress has acted to reassure FCS bondholders (and perhaps stockholders) of a government commitment to back FCS bonds, it has created legislation to coordinate internal self-help and to centralize decisionmaking in a way that makes the system more accountable to Congress. The effect of congressional action on bondholder confidence is illustrated by the changes in the yield spread between six-month Treasury and FCS securities. The spread rises from roughly zero from January through June of 1985 to around 20 basis points in July and August, then rises to a peak of around 80 basis points for September through November, and falls sharply in December, with the passage of the Farm Credit Amendments Act of 1985. Since then the spread has fallen and maintained itself at a level of approximately 20 basis points (through July 1986). 1986).

38. See Agricultural and Credit Outlook, '86 (Farm Credit Administration, January

39. For example, the Springfield, Baltimore, and Texas districts show very low percentages of nonaccrual loans (under 2 percent), while the Louisville, St. Louis, St. Paul, Omaha, Wichita, and Spokane districts all have nonaccrual loans in excess of 10 percent. Nonaccrual loans either are over 90 days contractually past due and inadequately secured or have been classified as a "loss" or uncollectible with respect to all principal and interest due. The districts show greater similarity with respect to the percentage of their overall portfolios deemed of "acceptable" quality—that is, loans not classified as "loss," "problem," or "vulnerable." Because the percentage of loans not deemed 
June 1983 all districts reported a ratio of "untroubled" to total loan items at Federal Land Banks in excess of 92 percent. By December 1985, six districts had fallen below 85 percent. Much of the variation in performance reflects relative degrees of diversification in regional economies. ${ }^{40}$

For our purposes, the ability of the FCS to function as an effective localized provider of agricultural credit is an important consideration, particularly when local banks may be vulnerable to fluctuations in farm income because of institutional restrictions on their ability to diversify risks. The FCS enjoys advantages over commercial banks both through an implicit government commitment to its debtholders and through a cooperative national network for spreading risk and merging troubled associations. At the same time, three specific features of FCS organization and rules-the method of arriving at interest rates on loans, cooperative stock ownership by borrowers, and the potential incompatibility of local and national goals-complicate coordination and portfolio management and decrease FCS effectiveness.

Its loan interest rate policy has encouraged relatively low-risk borrowers to leave the FCS recently. FCS interest rates, set on an averagecost rather than a marginal-cost basis, reflect the average interest cost on outstanding bonds, operating expenses, and past loan losses. When bond interest rates fall and losses from the past rise-as they did in the past two years-average cost exceeds marginal cost. By pricing at average cost, therefore, the FCS encourages borrowers who can retire debt or refinance it at competing institutions to do so, while at the same

acceptable is a reasonable predictor of future nonaccrual loans, one would expect the currently most troubled districts to continue to experience high relative stress, with the addition of the Sacramento district to the list of relatively high future losses. See Annual Report of the Cooperative Farm Credit System, various years.

40. The Springfield and Baltimore districts enjoy a relatively diverse economic base that sustains farmland values and offers off-farm employment opportunities during bad times for agriculture. Still, it seems not all of the differences among districts' FLB portfolio quality in 1985 can be attributed to different incidence of shocks. In 1979, at the end of the boom period, the seven districts with below-average ratios of performing unmatured principal-to-total loan items were Louisville, St. Louis, Omaha, Wichita, Texas, Sacramento, and Spokane. With the exception of Texas and Sacramento, these districts also show below-average portfolio quality in 1985 . Though such comparisons are not conclusive, they suggest that relatively liberal loan qualification standards may have played a part in the adverse recent experiences of some Land Banks. See Annual Report of the Cooperative Farm Credit System, various years. 
time it places unwarranted stress on borrowers who remain in the system. ${ }^{41}$

The cooperative nature of the FCS creates a further incentive for borrowers who can withdraw to do so. Upon taking out an FCS loan, borrowers must purchase FCS stock amounting to between 5 and 10 percent of the funds borrowed. When the loan is repaid, the purchase price-or a lesser amount if loan losses have reduced shareholders' equity to below par value-is reimbursed to borrowers; it is not possible to enjoy a capital gain on FCS stock. The threat of future equity losses leads borrowers in vulnerable districts to repay their loans prematurely in order to withdraw capital before expected portfolio losses are realized; it also encourages borrowers in relatively financially healthy districts to repay their loans before the impending consolidation of FCS stock by the new Farm Credit Capital Corporation eliminates the distinctions among districts' equity positions. The combined effect of high interest rates and expected capital losses on early " pay-downs" has been large. ${ }^{42}$ Because the borrowers leaving the FCS are likely to be among those of the highest quality, average-cost pricing and cooperative ownership are both further weakening the FCS portfolio.

Finally, conflicts between national- and district-level objectives have created problems for the FCS, both in the past and during the current period of transition toward centralization. Policies that are advantageous from a national perspective-loan interest rates that vary according to risk, for example-may be resisted in troubled districts, where managers prefer to keep borrowers' interest rates lower than true marginal cost and lack a strong incentive to protect the system's capital since they will be net recipients of a capital transfer in any case. At the same time, districts with relatively healthy balance sheets may be encouraged to

41. Average-cost pricing has created a widening interest rate differential between FCS intermediaries and their marginal-cost-pricing competitors. For example, in June 1986, interest rates on flexible-rate Federal Land Bank mortgages ranged from 11.5 to 12.5 percent, while insurance companies and commercial banks typically were charging rates on mortgages in the range of 10 to 10.5 percent-adjusting for mortgage fee differentials (see the Crittenden Ag Financing Newsletter, various issues, 1986).

42. Estimated pay-downs for the first five months of 1986 for all twelve districts totaled $\$ 1.6$ billion-roughly 2.7 percent of total FCS loans. District surveys indicate that the primary reason given for these pay-downs was high interest rates; the majority of borrowers who withdrew from the FCS switched to competing institutions. Loan pay-down data were provided by Robert Jensen of the Farm Credit Corporation of America. 
lend more freely, before the new Capital Corporation has a chance to implement its program of interdistrict capital transfers.

\section{FARMERS HOME ADMINISTRATION}

The Farmers Home Administration (FmHA), the "lender of last resort" for farmers, provides direct loans of various types, including Farm Ownership Loans, Farm Operating Loans, Economic Emergency Loans, and Economic Disaster Loans, as well as loan guarantees on loans made by other lending institutions. Applicants for credit must own or operate a "family-sized" farm, not so big that it requires a large proportion of hired labor, nor so small as to be considered a "rural residence." Further requirements are that the applicant have been refused credit from another lending institution; have experience as a farmer; be "creditworthy" (recent bankruptcy, delinquency, or a history of slow payments would be evidence to the contrary); and demonstrate a reliance on farm income. ${ }^{43}$

Credit supply restrictions to troubled borrowers in local loan markets need not be binding if government credit sources are sufficiently generous. Funding limits for the various FmHA programs are set by Congress, although until recently these limits did not really constrain FmHA lending. Typically, in the past, when one program's funding limits were reached, Congress increased funding or the Secretary of Agriculture transferred funds from another program. Since some loan programs, such as the Economic Disaster Program (ED), had unlimited "entitlement" status, the power to transfer funds from one to another effectively gave the Secretary of Agriculture an unlimited amount of lending authority. For example, in fiscal year 1985, the secretary transferred $\$ 1.7$ billion from the ED program to the direct Farm Operating Loan (OL) program and $\$ 460$ million from the ED program to the guaranteed OL program.

Two recent developments have made congressional lending limits binding. First, the volume of FmHA loan requests has risen markedly

43. The farmer's credentials—including a "Farm and Home Plan"- -are examined by local county supervisors whose decisions are approved on a pro forma basis by county committees. The Farm and Home Plan contains information on current debts and assets, as well as historical and projected cash flow. Loan qualification standards are the same for direct as for guaranteed loans. 
since 1984, as borrowers who previously depended on the FCS and commercial banks find themselves unable to secure credit without FmHA assistance-in the form either of a direct loan or of a loan guarantee. Total FmHA loans increased nearly 10 percent during fiscal 1985 to a level of over $\$ 29$ billion. Second, the entitlement-loan-program loophole was eliminated by the Food Security Act of 1985, which placed a ceiling of $\$ 1.3$ billion on the ED program.

In recent years, the portfolio of the FmHA has suffered more than that of any other major lending institution. By June 30, 1985, roughly 50 percent of FmHA loan principal was in delinquent loans, of which a majority have been delinquent for more than three years. As of December 1984, 40 percent of the FmHA borrowers had debt-equity ratios of greater than 70 percent and negative cash flow-twice the figure for commercial banks and the FCS and, presumably, a reflection of the poorer initial quality of FmHA borrowers. ${ }^{44}$ Another explanation for such a high proportion of loan delinquencies is the court-enforced moratorium on many FmHA foreclosures from 1983 through 1985, when the FmHA was forced to adopt uniform, detailed standards for informing borrowers of their rights and options, which include applying for rescheduling or for a five-year payment deferral.

Loan standards are tightening at the FmHA: rescheduling or deferral is permitted only in cases where the farmer can demonstrate long-run viability. By the end of fiscal 1985, the FmHA had received 108,710 applications for assistance by borrowers; 29,196 of these were granted a rescheduling, 15,794 were granted a debt set-aside, and 21,539 were rejected for reasons of inadequate cash flow. ${ }^{45}$ More than half of the 65,000 adverse action notices sent out by the FmHA so far this year will probably end in foreclosure. ${ }^{46}$

A further tightening of FmHA credit also seems imminent. As mentioned, congressionally imposed limits are now in force, as are tighter eligibility requirements for operating loans adopted in November 1985. In the past, the FmHA paid little attention to an applicant's ability to service other loans; now, a farmer who cannot pay off other debts in addition to the operating loan cannot be granted credit. This change, combined with the simultaneous increase in foreclosures, will force

44. Memorandum, Farm Credit Corporation of America, July 11, 1986.

45. Agricultural and Credit Outlook, '86, p. 40.

46. Estimate made by Jerry Hansen of the Center for Rural Affairs. 
many farmers who once qualified for FmHA forbearance to leave farming.

\section{New Directions for Farm Policy}

Radical changes in the structure of domestic and international agriculture since the major federal farm programs were established in the 1930s require that decisionmakers rethink the whole thrust of farm policy. Traditional price supports, acreage-reduction programs, and other government transfers, such as export subsidies, cannot alleviate distress in the farm sector at a reasonable cost. By contrast, federal intervention through credit markets will smooth the transition to a more market-oriented agricultural sector. Targeted income maintenance may be required to save particular groups of farms-such as the "family farm"--deemed socially valuable.

Our recommendations for reforms in agricultural credit markets center on our finding of the importance of "local" relationships between individual borrowers and financial intermediaries, arising from borrowers' lack of access to national credit markets, compounded by restrictions on the ability of certain lenders to diversify risks. The principal recommendations are two.

\section{MAINTAIN THE LONG-RUN HEALTH OF LOCAL LENDERS}

The government should focus its assistance on maintaining relatively efficient farm producers and financial intermediaries whose existence is threatened by the current crisis. As important repositories of scarce information capital, the FCS and private commercial banks serve as a conduit to those farmers who would be likely to meet the long-run discipline of the market but may fail because of short-run debt service constraints or unsupportable debt leveraging under current land values. Government assistance programs that recapitalize financial intermediaries and allow them to select optimally among potential recipients are superior to necessarily dispersed government-administered programs for debtors that rely on vague rules of thumb.

In addition, the fact that many shocks experienced in the farm sector are crop- or region-specific indicates the importance of promoting di- 
versification of the loan portfolios of agricultural lenders. ${ }^{47}$ Potential strategies include removing branching restrictions that limit the ability of local banks to pool risks; centralizing accounts of the Farm Credit System, which can borrow in national markets and pool risks across districts; and encouraging loan pricing based on marginal cost in the FCS so that borrowers' costs reflect forward-looking individual risk rather than past aggregate average cost. ${ }^{48}$

\section{EMPHASIZE LONG-RUN EFFICIENCY}

In an environment with substantial "openness" in farming and with extensive international competition, available funds should be distributed to maximize efficient farm production in the long run. A partial debt bailout or income-support program evenly dispersed among all farmers or among those who face the prospect of failure is unlikely to work. Depending on how one defines "vulnerable" debt, the proportion of vulnerable to total debt varies between one-third and one-half. ${ }^{49}$ Focusing scarce government assistance on relatively efficient producers by channeling aid through financial intermediaries would thus be a more effective, as well as efficient, means of aiding distressed farmers than price or income supports.

We have little to say about the issue of "saving the family farm." Indeed, the dramatic changes in productivity and in the structure of agricultural markets have complicated any operational definition of "family farms." Still, effective policies will be those targeted toward well-defined groups (as with the credit reforms suggested above). Given this targeting, it is likely that income-maintenance programs will be needed to keep in business some groups of farms felt to be socially desirable. The temptation to alter farm prices to achieve these political

47. Encouraging horizontal (crop) diversification for individual farmers would also be helpful, but the ability to diversify meaningfully is region-specific.

48. The elimination of branching restrictions is, of course, a good idea for other reasons having little to do with agriculture. We emphasize the idea here for three reasons. First, it illustrates well our point that localized lenders may experience difficulties in servicing the credit needs of agricultural borrowers. Second, it points up the value of the operations of the Farm Credit System in a loan market with branch-banking restrictions. Finally, it is interesting to note that, while farm interests have historically supported the idea of small banks with no branching, such a system may no longer be in their best interest.

49. See Melichar, "Agricultural Banks," p. 444; and Agricultural and Credit Outlook, '86, pp. 27-9. 
goals should be avoided in the interest of both economic efficiency and budgetary cost.

\section{Conclusions}

As international trade in farm products has expanded, so has the sensitivity of farm incomes to fluctuations in domestic and world economic conditions. Thus, while the price-stabilization, acreagereduction, and related policies in place since the 1930s were relatively successful in stabilizing farm income during the 1950s and 1960s, they are likely to be less effective in achieving this goal in the future.

Analysis of the state panel data indicates that disruptions in agricultural credit markets can have real effects on farm output. That finding is consistent with the conventional wisdom that, unlike credit markets for large firms or for firms for which monitoring is less costly, agricultural financial markets require close customer arrangements. Local financial institutions, for which such relationships are best developed, are often unable, for institutional reasons, to diversify their loan risks, either within agriculture or across other geographically separated activities. The deviations from perfect markets indicate an economic rationale-in addition to the usual political, social, and national defense rationalesforgovernment intervention in agricultural credit markets. Our empirical evidence supports the view that attempting to maintain customer relationships should be an important objective of the FDIC when handling failed or failing farm banks. Because of the Farm Credit System's ability to pool agricultural loan risks nationally and because of its access to national capital markets, the FCS will continue to be an important lender in agricultural credit markets.

\section{APPENDIX}

\section{State Panel Data}

THIS APPENDIX provides definitions and sources for the state panel data base covering twenty-four states from 1977 through 1984. 
$Q=$ Cash receipts from farm marketings/P

$D S=I N T / I N C$

$D / E=$ Debt/Equity,

where:

Cash receipts from farm marketings is from U.S. Department of Agriculture, Economic Research Service, Economic Indicators of the Farm Sector: State Income and Balance Sheet Statistics 1984 (GPO, 1986), table 4.

$P=$ a price index constructed by weighting an annual series of national commodity prices by the quantity of output produced in 1980 for the five agricultural products of each state with the greatest sales in 1980 . The annual price data from 1977 through 1984 are from U.S. Department of Agriculture, Agricultural Statistics (GPO, 1985). The cash receipts for the top five products in each state in 1980 were taken from Economic Indicators of the Farm Sector: State Income and Balance Sheet Statistics 1980, table 2. The products used to construct this index were cattle, dairy, soybeans, corn, wheat, hogs, broilers, cotton, eggs, tobacco, hay, rice, turkeys, grapes, potatoes, oranges, sorghum, apples, forestry, tomatoes, green peas, sugar beets, barley, dry beans, and peanuts. "Nursery and greenhouse products" were excluded because of ambiguities associated with the price for these products.

$R E=$ the average real value (deflated by the GNP deflator) of farmland in the state, as of January 1, obtained from U.S. Department of Agriculture, Farm Real Estate Market Developments: Outlook and Situation Report (GPO, 1984).

FAILS $=$ the number of Federal Deposit Insurance Corporation board actions (liquidations and forced acquisitions and mergers) pertaining to commercial banks in each state in each year, collected from Annual Reports of the Federal Deposit Insurance Corporation, 1977-1984.

Loan Charge-offs = net loan charge-offs as a percentage of total loans at agricultural banks in each state in each year, from Emanuel Melichar, "Agricultural Banking Experience, 1985" (Preliminary Data Appendix, Board of Governers of the Federal Reserve System, March 8, 1986), table E.7. 
$I N T=$ total interest payments on debt, collected from Economic Indicators of the Farm Sector: State Income and Balance Sheet Statistics 1980, tables 11-12; and 1984, tables 25-30.

$I N C=$ gross income of the state farm sector, from Economic Indicators of the Farm Sector: State Income and Balance Sheet Statistics 1980, table 4 ; and 1984 , table 5.

$F S=$ the fraction of total sales in 1982 , by state, generated by farms with sales per farm falling between $\$ 40,000$ and $\$ 99,000$ (1982 dollars), collected from the U.S. Bureau of the Census, 1982 Census of Agriculture, vol. 1, Geographic Area Series (GPO, 1982), table 3.

$D e b t=$ the estimated market value of total farm debt as of January 1 from Economic Indicators of the Farm Sector: State Income and Balance Sheet Statistics 1984, tables T43-T44.

Equity = the estimated market value of total farm equity as of January 1 from Economic Indicators of the Farm Sector: State Income and Balance Sheet Statistics 1984, table B2. 


\section{Comments and Discussion}

Benjamin M. Friedman: The surprisingly rapid evolution of the U.S. economy's agricultural sector from world bread basket to worrisome basket case has raised important public policy issues and, at the same time, provided a case study for examining some interesting questions about economic behavior. Calomiris, Hubbard, and Stock seek to address both dimensions of this situation. They first use the farm sector's recent experience to test some familiar ideas about how and under what circumstances credit availability and credit rationing affect nonfinancial economic activity. Then they go on to offer specific policy conclusions and recommendations. I shall discuss the two parts of the paper separately.

The heart of the authors' analysis of the role of credit markets in the farm sector is an effort to construct an empirical model linking agricultural production to credit market variables suggested by the credit rationing literature stemming most recently from the work of Stiglitz and Weiss. The authors argue that agricultural producers are especially likely candidates for the application of a Stiglitz-Weiss model because of the inability of creditors to gain essential information about borrowers' production prospects. As a result, creditors face an adverse selection problem, therefore ration credit, and thereby restrict agricultural production.

Calomiris, Hubbard, and Stock point to two ways in which the market can avoid this trap, and build much of their empirical analysis around them. First, as in the original Stiglitz-Weiss presentation, borrowers can enhance their access to credit by putting up collateral. In the case of farms, the available collateral consists largely of land, and the value of agricultural real estate is a key variable in the authors' empirical work. 
Second, credit institutions that are somehow able to acquire and process the kind of information necessary to overcome the adverse selection problem can clearly play a major role in such a setting. The authors argue that local banks in agricultural communities in fact can and do accomplish that task, and therefore that impaired ability of such institutions to function normally in turn restricts agricultural production. A second key variable in their empirical analysis is therefore the failure rate among predominantly agricultural banks.

Before proceeding to criticize several aspects of this analysis, I think it appropriate to applaud the basic thrust of the paper. Most economists have long recognized that many aspects of economic behavior are difficult to reconcile with our everyday theoretical toolkit if we maintain the assumption of universal access to perfect credit markets. At the most basic level, for example, neither Clower's story of how temporarily income-constrained households reduce their demand for goods and services nor Patinkin's story of how temporarily sales-constrained firms reduce their demand for labor would make much sense if households and firms could readily borrow against future labor income and the proceeds of future sales. Some form of credit market constraint must presumably be implicit in both cases.

Nevertheless, for many years the literature on credit market constraints remained relatively undeveloped. One reason was the concern, voiced by Samuelson and others, over why profit-maximizing lenders would ration credit to any borrower, rather than simply raise interest rates to clear the loan market. The literature now identified with Stiglitz and Weiss has effectively addressed that concern, using the concepts of imperfect information and adverse selection. Another reason for the sluggish development of this literature has been the difficulty of finding empirical support for either the existence or the effects of credit rationing in work based on aggregate data.

Calomiris, Hubbard, and Stock are on the right track, I believe, not only in grounding their analysis in the Stiglitz-Weiss model, with the consequent emphasis on collateral and the role of specialized local lending institutions, but also in looking beyond the conventional macroeconomic time series for evidence. This they do not only by isolating the farm sector, already only one-twentieth of the U.S. economy, but also by using data disaggregated by state. In the end their empirical results are mixed, as is to be expected from the use of data that are still 
fairly aggregated. Even so, the results do indicate significant roles for both the real estate collateral variable and the bank failure variable. To be sure, one could offer numerous quibbles about what is omitted from the key equation, as well as about how to interpret what is included. On the whole, the authors do a good job of anticipating such questions, however, and I think the paper provides more interesting issues to discuss anyway.

My principal concern about this part of the paper is that the authors never spell out explicitly how limitations on credit availability restrict agricultural production in the short run. (By contrast, they offer a good discussion of effects on such long-run matters as soil conservation.) Just what are farmers who are denied credit presumed to do? Do they plant less, or not plant at all? Is production itself quantity-constrained in some way? If so, what is the constraining quantity? Do they sell out? If so, to whom? And what then affects the buyers' production decisions? Do they liquidate? If so, would bankruptcies be a sufficient statistic for the credit market effects that the authors have in mind?

Having an explicit view of the links connecting credit availability to production decisions would advance this line of research in two ways. First, it would place the authors on firmer ground in specifying and then interpreting their key equation-which, to recall, relates real production on the left to hypothesized determinants of credit availability on the right. Second, it would probably suggest additional relationships to investigate, either by-products consistent with their main hypothesis or perhaps a well-specified alternative that could potentially refute it.

I found the paper's policy conclusions less compelling than the conceptual thrust of the preceding analysis. The authors offer two policy recommendations. One is to maintain the health of local agricultural lenders by such devices as government-assisted recapitalization programs, elimination of laws prohibiting branch banking, and several reforms of the Farm Credit System. The other is to emphasize the longrun efficiency of domestic agriculture by focusing government assistance on efficient producers, using local financial intermediaries to do the focusing.

Although it is difficult in principle to disagree with policy recommendations of the form "maintain the health of . . . (you fill in the blank)" and "emphasize the long-run efficiency of . . . (again your choice in the blank)," I do have some reservations that I will state as questions. 
To begin, how unique is the credit situation of the agricultural sector after all? The authors are at pains to describe the lack of product and asset diversification and the positive correlation between cash-flow risk and asset risk that are typical of most farm producers. Is either feature really all that different among small manufacturers? In an era in which we continually hear about the large share of GNP and the larger share of new job creation generated by small business in the United States, would a parallel analysis lead the authors to find a Stiglitz-Weiss-style credit market imperfection warranting government intervention in favor of small businesses generally?

Next, what part of the authors' recommendations for financial reform is really specific to the agricultural sector? For example, laws prohibiting branch banking are well worth repealing for reasons that have nothing to do with agriculture. Similarly, proposals abound for recapitalizing lending institutions that have gone under water, again usually with little or no necessary tie to the farm situation. Are the authors saying something new here by at least providing a new first-magnitude argument for such steps? Or does their analysis just provide another in a long list of reasons for doing what seems sensible anyway?

Finally, and most fundamentally, is it plausible to suppose that largescale government support, even if channeled through financial intermediaries with varying degrees of privateness, will really facilitate a transition to a more efficient productive system rather than just further entrench existing inefficient producers? The question is applicable to any large-scale support program, but it is especially appropriate to ask it about the U.S. farm sector in the 1980s. With the extraordinary explosion of the cost of direct federal assistance to agriculture, not to mention a great variety of hard-to-price indirect aids, it has become increasingly clear that this decade's supposed effort to reduce welfare programs is really just a (presumably political) matter of substituting one group of recipients for another. Food supports and aid to farmers with defective crops have become drains on the federal budget on a scale that food stamps and aid to families with dependent children never were. Are our farms now being buffeted by volatile world markets, as the authors argue, or have they simply not yet adjusted to an advancing world agricultural revolution that has by now rendered India a food exporter and even Bangladesh self-sufficient? Has our traditional agricultural surplus in foreign trade vanished because of unfair competition abroad 
or because the government in the 1980s has adopted the policy of supporting crop prices at levels above world market levels? Policy recommendations for the farm sector can be persuasive only if they address questions like these.

\section{General Discussion}

Matthew Shapiro questioned the importance of asymmetric information in farming, noting that, since farming is carried out in the open air, lenders can easily see how business is going. Thomas Juster added that bankers in small towns have probably known the farmers they serve for decades and that both banker and farmer are looking at the same information on prices, yields, total output, and other relevant variables. Kenneth Judd defended the view that there are considerable information asymmetries in farming, noting that it would be neither feasible nor socially acceptable for rural bankers to monitor directly their clients' activities. It may be difficult to determine whether loans to any particular farm are a good bet, since there is only one observation on each farm's income and output per year.Charles Calomiris reported that Farm Credit System officials regard asymmetric information as very important in farming and that they devote considerable effort to compiling historical cash-flow and debt-equity ratios to help in determining the most efficient farmers.

Katharine Abraham questioned whether the evidence in table 6, showing that small farms' sales have grown much less rapidly than large farms' sales, truly reflected differential access to credit. She suggested it could as well reflect differences in desired growth by different types of farmers. Many small farms are operated by part-time farmers who work full-time at other jobs and farm for enjoyment. Calomiris responded that while small, part-time farmers may have chosen not to expand their operations, numbers not presented in the table indicate that moderatesized farms, presumably operated by full-time farmers, grew relatively slowly as well.

Gregory Mankiw asked why farmers have not done more to hedge against movements in the prices of agricultural products. Lawrence Summers noted that farmers face variability in both price and output, which means that they cannot fully hedge expected output against changes in price. Not knowing how large their crops will be, farmers 
would run considerable risk if they were to hedge a quantity close to their expected production, since actual yields might turn out to be lower than expected. Summers also suggested that, in principle, farmers could spread their risks by incorporating and selling shares in their operations on the open market. Benjamin Friedman responded that it would not be feasible for shares in organizations the size of the typical farm to be traded on the stock market, but he suggested that one might ask why the basic agricultural unit is not a larger, more diversified agglomeration.

Alan Blinder applauded the authors' success in identifying a sector where one can reasonably hope to sort out the effects of credit availability. He likened the issues developed in this paper to those raised in the debate over the effects of disintermediation on credit availability for housing. Separating the holding of farm loans from the making of the loans, as in the home mortgage market, might help the farm credit situation, Blinder concluded. Richard Cooper pointed out that local knowledge was more important in the farm credit market than in the mortgage market, not only for deciding whether to make a loan in the first place, but especially for deciding whether to foreclose on the loan. That being the case, farm loans should be kept local. 